\title{
Textural features of the beach sediments of Wast Water Lake, Northwest England
}

Abstract

This study is dedicated to Wast Water Lake (Northwest England, Great Britain) and the character of its beach sediments. The aim of the study is to identify the textural features of the lake's beach sediments based on two methods. The first is a granulometric analysis and the second a pebble shape analysis according to Zingg (1935) and Sneed \& Folk (1958). Both analyses were carried out for all of the lake's accessible beaches and the cliffs adjacent to them. The transport and deposition history of the examined sediments was identified through field research and laboratory analysis. The results show that the textural features of the sediments at Wast Water are more often typical of a fluvial environment, rather than having been changed by lacustrine water movements.

Keywords

English Lake District $\bullet$ beach sediments $\bullet$ granulometric analysis $\bullet$ pebble shape analysis • littoral zone $\cdot$ Wast Water

(C) University of Warsaw - Faculty of Geography and Regional Studies

\author{
Emilia Bala
}

Faculty of Geography and Regional Studies,

Uniwersity of Warsaw, Poland

e-mail:Emilia_bala@wp.pl
Introduction

Lake littoral zones is not a very common topic in geomorphological research. There are many more case studies for sea beaches, which concentrate on both beach sediments and coastal relief. Such investigations have been done by many researchers from all over the world, such as Hart \& Plint (1995), Bluck (1999), Bluck et al. (2001) and Dashtgard et al. (2006). These authors have focused not only on the processes that lead to the development of beaches, but also the relief forms that are formed by sea water movement such as waves and coastal currents. The subject of pebble sorting on marine beaches has been studied often (Bluck 1999; Bluck et al. 2001; Neal et al. 2002).

Research on lake coastal zones has concentrated exclusively on erosion processes and changes in shoreline range (Korolec 1968; Herdendorf 1973; Kirk et al. 2000). Research on lake sediments has been led by several scientists; however, they concentrated on big lakes, such as Lake Victoria (Webb et al. 2012), Michigan (Cahill 1981), Erie (Kemp et al. 1974, Schelske \& Hodell 1995), Ontario (Thomas et al. 1972; Herdendorf 1973; Kemp et al. 1974), Huron (Thomas et al. 1973; Kemp et al. 1974), and the transport of sediments within the lake basin (Hilton 1985; Hilton et al. 1986). The identification of lacustrine sediments as a natural archive of climate change is also very common and has been examined, for example, by Wicik \& Więckowski (1991), Kemp (1996), Starkel, (1998), Meyers \& Lallier-Vergès (1999), Tian, Nelson \& Sheng Hu (2011) and Tylmann (2011). Research on lake beach sediments has been conducted by Starkel (1998) and Rutkowski (2001) (Rutkowski et al. 2003), Srinivas \& Sajan (2010) and Winter (2012). These studies have been conducted on certain lakes in Poland, India and New Zealand. The main purpose of these research studies was to define whether the processes existing at a lake's shore zone are comparable to marine processes and to determine the main impact on lake sediments. Clast sorting issues have also been taken into account.

Even though research on sea coastal zones is highly developed, it is very difficult to compare the processes with lake coastal zones because of the completely different intensity of the two environments. Furthermore, it is important to take into account the size of the lake being examined, because both sediment movement and coastal processes coincide in different conditions and with different intensities (Sly 1978, Winter 2012). There remains a deficit of research regarding this environment.

The main purpose of this study is to identify the textural features of beach sediments around Wast Water (Northwest England), their transport and deposition history. The author will also attempt to answer the question of whether there is a visible clast sorting process at Wast Water's shore zone and to determine the impact of existing processes on sorting sediments in its shore line range. The distinction of beach sediments and processes within the shore zone indicates the origin of the sediments and the dynamics of water movement.

\section{Description of the study area}

Wast Water (Lat. $54^{\circ} 24^{\prime} \mathrm{N}$, Long. $3^{\circ} 18^{\prime} \mathrm{W}$ ) is the deepest lake in England with a maximum depth of $76 \mathrm{~m}$, a surface area of $2.8 \mathrm{~km}^{2}$ and a catchment area of $48.5 \mathrm{~km}^{2}$. It is situated in the western part of the Lake District National Park in Northwest England (Fig. 1) and is located in a very wide, flat-bottomed valley. It is a polygenetic lake as it developed in a tectonic fault zone which was deepened by glacial processes (Boardman 1996). Characteristic features that are very prominent in the area are hills with an altitude of less than $1000 \mathrm{~m}$ with steep slopes where screes developed during the postglacial period. 


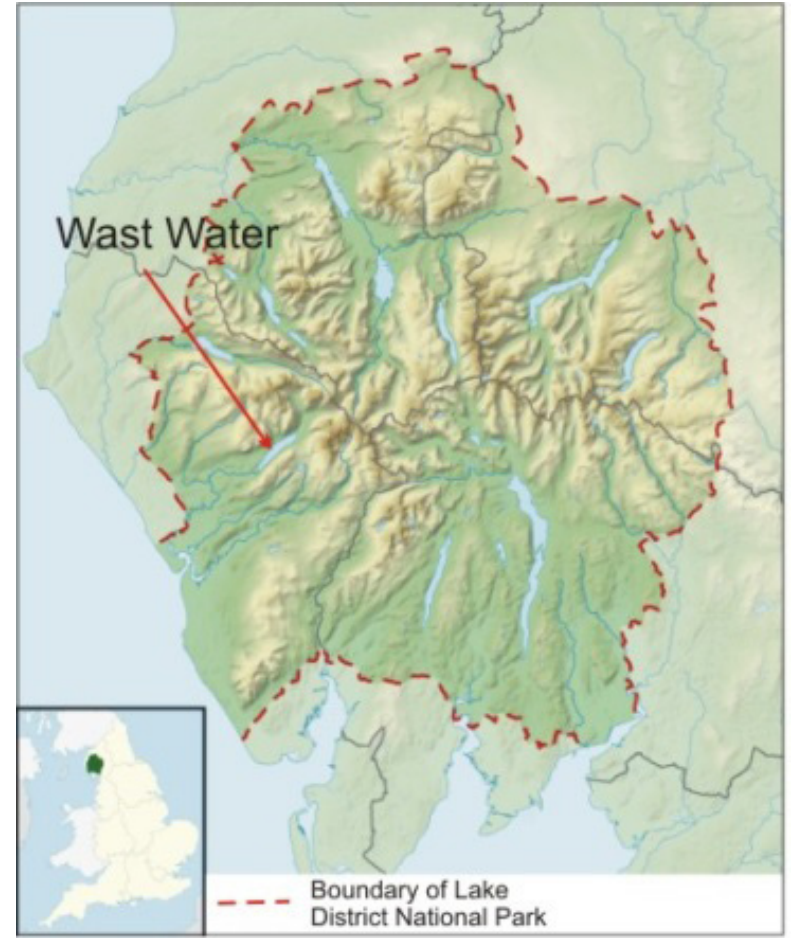

Figure 1. Location of the study area (image source: https://en.wikipedia.org/wiki/Scafell_Pike)

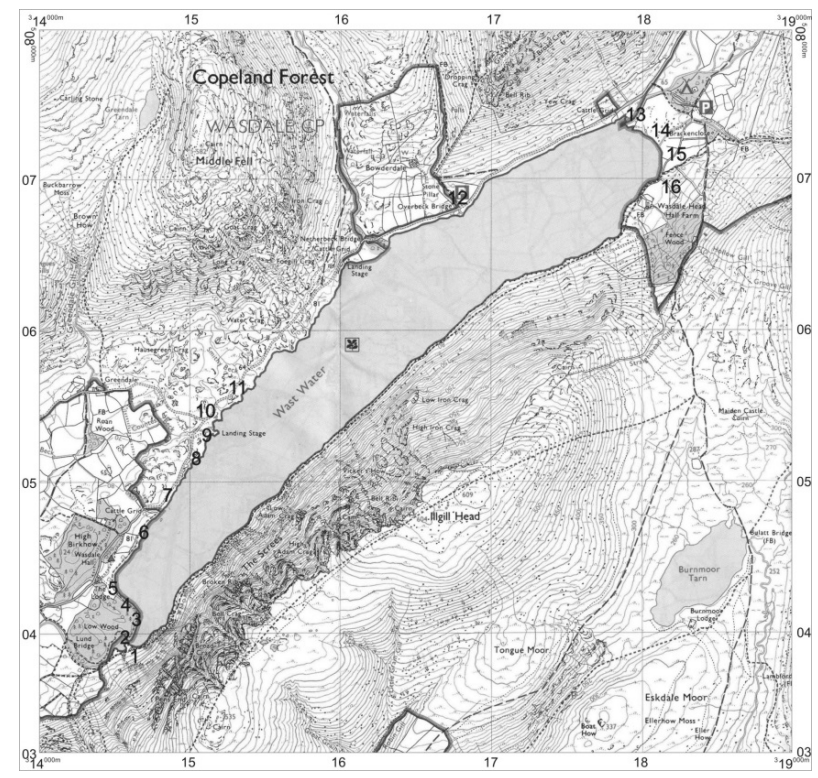

Figure 2. Own eleboration based on The English Lake District Map, South- Western area, Coniston, Ulverston \& Barrow-in-Furness; Explorer OL6; 1:25 000, Ordnance Survey, Southampton, United Kingdom, 2002, Crown copyright Ordnance Survey. All rights reserved

Wast Water has a very regular shore zone. The most developed part of the shore is to the north of the lake, and is influenced by contemporary processes. Along some parts of the lake there are a few small gravelly beaches as well as delta sediments and steep stony edges. There are also quite a few gills flowing into Wast Water Lake, but there is only one river, which is at the southwest end of the lake - the River Irt, which flows out of the lake.
The length of the Wast Water shore zone is $11.6 \mathrm{~km}$ and consists of beaches and river deltas $(6 \mathrm{~km})$, screes $(2.6 \mathrm{~km})$ and rock edges $(3 \mathrm{~km})$. The most changeable parts of the shore zone are the beaches and river deltas. The screes are still active only in regions that are not covered by plants (Boardman 1991).

Beaches on Wast Water take up more than $50 \%$ of the whole lake's shoreline. Most of them were created by gills and are presumably accumulative in origin. The others are situated by ridges made out of till; these seem to be erosion beaches. The biggest beaches are located next to the River Irt (no. 1, 2, 3 on location map, Fig. 2). Deltas were created by the rivers Countess Beck (test point 9), Over Beck (12), Mosedale Beck/Lingmell Beck and Lingmell Gill $(13,14,15)$. The beaches on Wast Water are not big; their sizes range from 0.5 to $6 \mathrm{~m}$ in width and from 3 to $12 \mathrm{~m}$ in length. The cliffs are rather small with a height of less than $0.5 \mathrm{~m}$ (points $7,8,10,11,12$ on the location map, Fig. 2), some of them occurring near deltas. The cliffs are located mostly in the western part of the lake. Most of the edges are made of a very cohesive till with small-grained gravels, with a low occurrence of bigger pebbles.

Only the active parts of the lake shore were chosen for this research, with the exception of the screes (southeast part of the lake), which are not accessible. The selection was dictated by accessibility and the types of sediment that built the examined forms.

\section{Methods}

Three methods have been used in the distinction of lake beach sediments: grain size distribution according to MycielskaDowgiałto \& Rutkowski (1995), and shape of clasts following Zingg's method (1935) and Sneed and Folk's method (1958).

For a grain size distribution analysis (Mycielska-Dowgiałto \& Rutkowski 1995), samples from all suitable beaches were obtained. Samples labelled "a" were taken from areas closest to the water and those labelled "e" were from areas furthest from the water in the beach profile, which gave 40 samples taken from 16 beaches. Samples were taken from underneath the pebble pavement on the beaches. A granulometric analysis was conducted on those samples. For this analysis, the author used sieves to separate fractions $4 ; 2 ; 1 ; 0.8 ; 0.5 ; 0.315 ; 0.25 ; 0.18 ; 0.125 ; 0.1$; and $0.063 \mathrm{~mm}$. The sediment data were processed using Gradistat 5.11 PL beta software for the indexes of mean grain size $(\mathrm{Mz})$, standard deviation $\left(\sigma_{1}\right)$ and skewness $\left(S_{1}\right)$ (Folk \& Ward 1957), and presented in correlation diagrams (Mycielska-Dowgiałło \& Ludwikowska-Kędzia 2011).

For Zingg's (1935) and Sneed \& Folk's (1958) methods, 7-10 cm stone fragments were used from all possible forms, such as cliffs made of till and beaches. The selection of these forms was determined by the size of available particles. For shape classification analysis, 30 clasts from 11 beaches and 5 cliffs were used, which gave 480 clasts for analysis. The analysis of both Zingg (1935) and Sneed \& Folk (1958) requires measurements of three axes of the examined clasts, where axis a is the longest, $\mathrm{b}-$ the intermediate and $\mathrm{c}$ - the shortest. For shape distinction it is necessary to calculate the relationship between axis $b$ and axis $a$, and between axis $c$ and axis $b$. The results of the calculations are presented in the diagrams (Fig. 3).

\section{Results and discussion}

Grain size distribution analysis

Sediments from the examined beaches on Wast Water are mostly sand and fine grained gravels with a mean grain size $(\mathrm{Mz})$ above $1 \mathrm{~mm}$, but not exceeding $3 \mathrm{~mm}$; meanwhile, some bigger pebbles have a grain size of up to $10 \mathrm{~cm}$. Differentiation exists between the beaches: on sites 1, 2, 3, 4, 5, 6, 13, 14, 15, and 16 (Fig. 4), Mz values ranged from 2 to $4 \mathrm{~mm}$, which indicates 

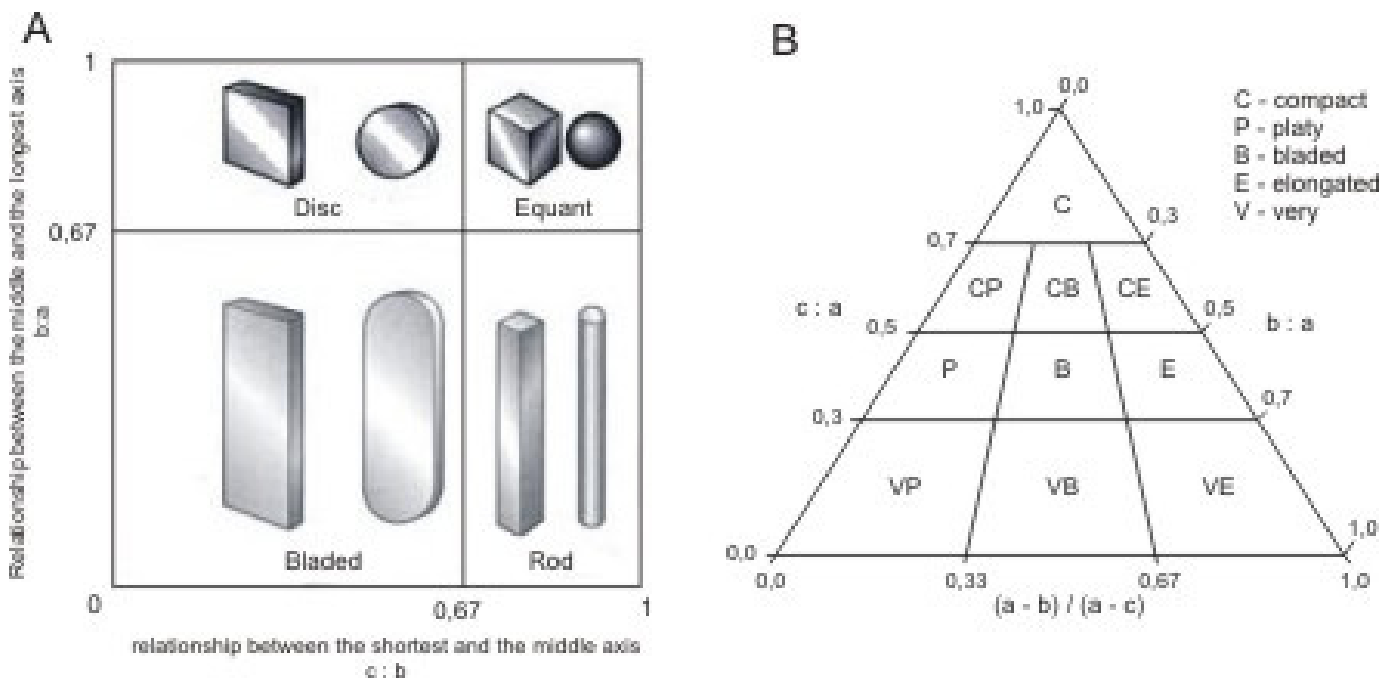

Figure 3. A. Zingg's diagram (1935), B - Sneed \& Folk triplot diagram (1958)

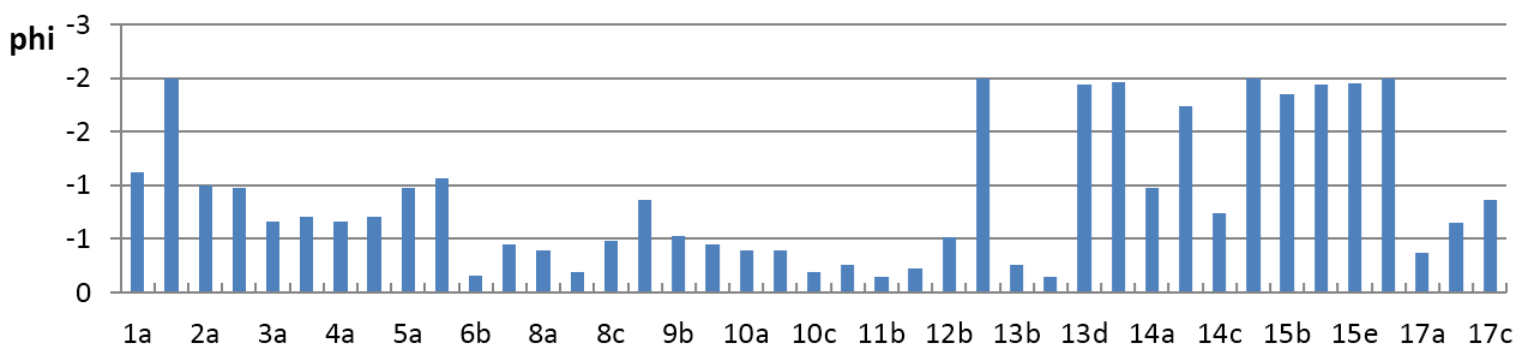

Figure 4. Mean grain size in beach sediments

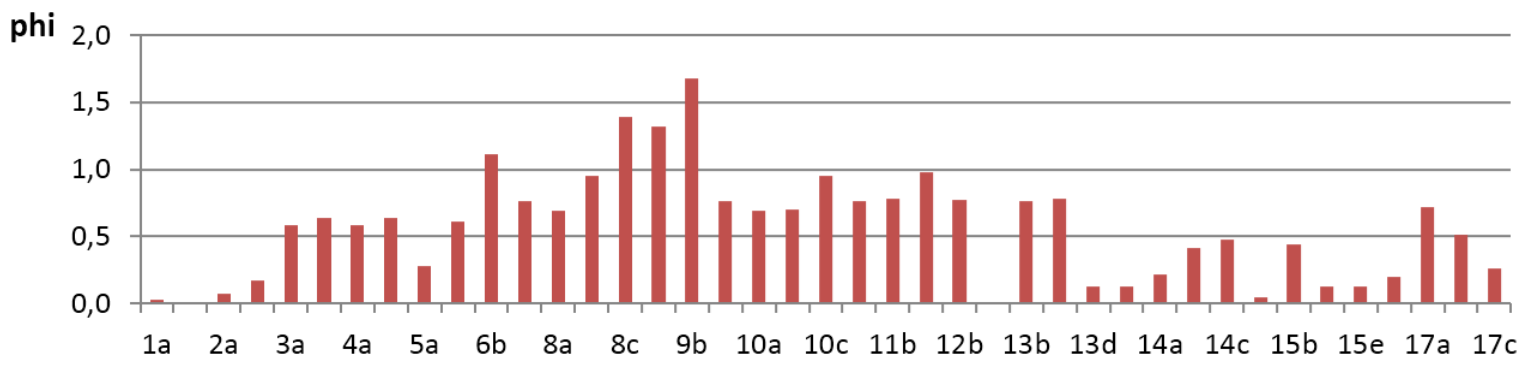

Figure 5. Standard deviation values in beach sediments

fine gravel and very fine gravel, while on sites $7,8,9,10,11,12$ and 17 (Fig. 4), the mean grain sizes are less than $1 \mathrm{~mm}$ (very coarse sand). Mz values differ according to the beach profile, as the smallest grains are noticed closest to the water and the mean grain size increases in the direction of the land. The biggest values of $\mathrm{Mz}$ are observed on sites that are influenced by rivers flowing into the lake. Meanwhile, the smallest grains are on the beaches adjacent to till cliffs (Fig. 4).

The beach sediments are rather poorly sorted, as shown by standard deviation values $\left(\sigma_{1}\right)$ (Folk \& Ward 1957) ranging from 0.5 to 1.65 . In some cases (beaches no. 1, 2, 13, 14, 15 and 16 according to the location map, Fig. 2), standard deviation values ranged from 0.0 to 0.17 phi (Fig. 5), which indicates well-sorted sediments. The reasons for this probably relate to different factors, since those beaches are far from each other. Points 1 and 2 are situated in the south-western part of the lake by the River Irt, which drains the lake. However, sampling points 13 , $14,15,16$ are situated precisely on the other side of the lake (the north-eastern part) on the delta, which was created in the late Pleistocene and Holocene (Harvey 1997) by gills streaming down from Scafell Pike (Lingmell Gill), Pillar and Great Gable (Mosedale Beck, Lingmell Beck). In both cases, the sorting of sediments might have been influenced by a long period of transport; in the first case this could be wave transport, and in the second fluvial transport.

On the other beaches $(3,4,6,7,8,9,10,11,12,17)$, sediments are moderate and poorly sorted; standard deviation values range from 0.5 to 1.65 phi (Fig. 5). At sites 9, 10 and 12 there has presumably been a fluvial influence on the sorting of sediments, as those beaches are situated by the deltas 
of the Countess Beck and the Over Beck. In the other areas, the sediments are of glacial origin and come from cliffs made out of till. This is confirmed by standard deviation values for till sediments ranging from 0.5 to $1.3 \mathrm{phi}$. In all cases there is a visible differentiation according to the beach profile, where the best-sorted sediments are usually nearest the water and the sorting gets worse with distance from the water zone. Furthermore, at sites $7,9,10,11,12$, the beach sediments were compared to the sediments from the cliffs adjacent to them. Mean grain size values ranged in both beaches and cliffs between 0.0 and $-0.7 \mathrm{phi}(1-1.5 \mathrm{~mm})$ with smaller grains occurring in the cliffs (Fig. 6). In general, sediments are moderate and poorly sorted ( $\sigma_{1}$ ranged between 0.5 to $1.7 \mathrm{phi}$ ) (Fig. 7 ). In this case it is likely that smaller grains had been washed out from the beach by the wave processes that occur on the lake.

Analysis of the relationship of Folk \& Ward textural parameters

Textural parameters calculated according to Folk \& Ward (1957) are plotted in Fig. 8 together with previous genetic interpretations of lacustrine beach sediments by Ludwikowska-Kędzia (2000) and Mycielska-Dowgiałło \& Ludwikowska-Kędzia (2011). The relationship between mean grain size $(\mathrm{Mz})$ and standard deviation $(\sigma 1)$ (Fig. 8A) shows that the examined sediments were transported in a high-energy environment and accumulated on the frontier of the river channel deposits (Mycielska-Dowgiałto \& Rutkowski 1995, 2007; Ludwikowska-Kędzia, 2000), because the data set does not fit the field characteristic for river channel deposits and expands into fields with a bigger mean grain size and worse standard deviation values. (Mycielska-Dowgiałło \& Ludwikowska-Kędzia 2011). A comparison of those points with correlations described by Mycielska-Dowgiałło (Mycielska-Dowgiałło \& Rutkowski 1995; MycielskaDowgiałło \& Ludwikowska-Kędzia 2011) suggests that the most common occurrences can be correlated with environments of differentiated dynamics and rapid deposition, such as in river bed lag deposits. A larger divergence in Ludwikowska-Kędzia's (Ludwikowska-Kędzia 2000; Mycielska-Dowgiałło \& Ludwikowska-Kędzia 2011) correlations is visible in the relationship diagram between Sk1 and Mz (Fig. 8B), where the biggest cloud of points lies on the boundary of the field characteristic for river channel deposits, with lower values of skewness and smaller mean grain size. Most of the points do not fit into the fields designated by LudwikowskaKędzia (2011). This means that the transport occurred in a highly energetic environment, such as a flash flood, and deposition was rapid, as the sediments are represented by coarse sand, very fine gravel and fine gravel ( $\mathrm{Mz}$ from $1 \mathrm{~mm}$ up to $4 \mathrm{~mm}$ ) and are poorly sorted $\left(\sigma_{1}\right.$ in the range of 0.5 to $\left.1.5 \mathrm{phi}\right)$.

The worst correlation between the fields designated by Ludwikowska-Kędzia (Ludwikowska-Kędzia 2000; Mycielska-Dowgiało \& Ludwikowska-Kędzia 2011) are shown in the relationship diagram for skewness $\left(\mathrm{Sk}_{1}\right)$ versus standard deviation $\left(\sigma_{1}\right)$ (Fig. $\left.8 \mathrm{C}\right)$. The biggest cluster of points range in value between $\mathrm{Sk}_{1}=0.4-1$ and $\sigma_{1}=0-3$, placing it only just within the field characteristic for overbank-pool deposits.

The fluvial environment is the most significant for the textural features of the beach sediments at Wast Water's beaches, with a smaller impact of lacustrine water movements on sorting sediments. It can be suggested that water movements can have an influence on washing away finer fractions from the pebble pavements.

\section{Pebble shape analysis}

For the pebble shape analysis, according to Zingg (1935) and Sneed \& Folk (1958), 30 clasts were taken into account from each examined form, ranging in size from 7 to $10 \mathrm{~cm}$. All of the clasts measured were calculated in excel and are presented in the diagrams (Fig. 9-10).

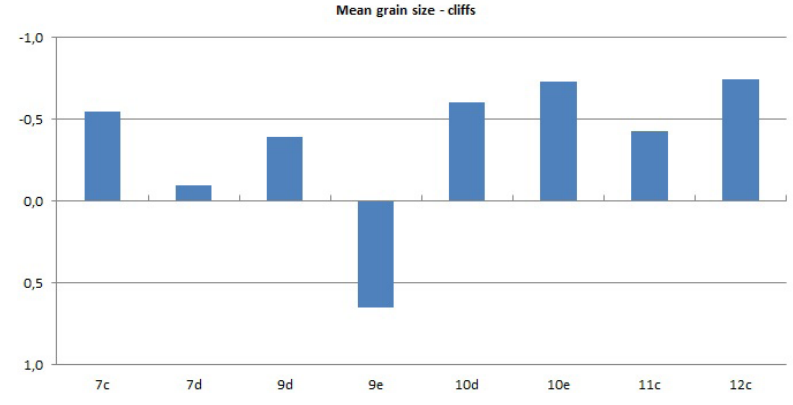

Figure 6. Mean grain size values in cliffs sediments

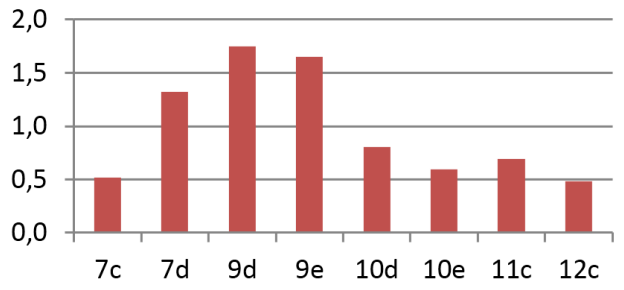

Figure 7. Standard deviation in cliffs sediments

For comparison, measures were also made of clasts in the cliffs adjacent to the beaches and river deltas $(8,10,11,12,13$, 14 according to location map, Fig.2).

The result of this analysis shows that the types that occur most often on beaches are rod shaped $(30 \%$ of all clasts examined) and discoid shaped pebbles (29\%). The pebbles that occur least are blade shaped (17\%). In cliffs the most commonly occurring shapes are discoid (34\%) and equant (29\%).

There is also a differentiation between some of the beaches (Fig. 11). Rod and discoid shaped pebbles are most frequent on beaches $1,10,13,14$, while at sites 2,12 , and 16 , the most frequent are rod and equant shaped pebbles (Bala 2012). The predominance of discoid shaped pebbles, which are characteristic for beaches, occurs only at a small number of sites (sites 8,9 , 11; Fig. 11).

Only on beach 15, which is situated beyond Mosedale Beck's and Lingmell Gill's influence, do discoid pebbles occur more frequently $(33 \%)$, as well as bladed and rod shaped pebbles $(23 \%$ each). A different situation is found regarding pebbles that come from the cliffs, with the most frequent being discoid and equant shapes (Fig. 11). Both of these shapes make up more than $60 \%$ of all clasts. The clast shapes found on erosional beaches do not correlate with the clast shapes found in the cliff sediments (Fig. 11). This also indicates that there is a relatively similar impact of water movements and fluvial transport on beach sediments, as discoid shaped clasts come from cliffs in some cases.

The results from the above analysis show that beaches created by rivers are represented by a majority of rod and discoid shaped pebbles, which are typical for fluvial transport and waving. However, pebbles on erosion beaches do not demonstrate sorting when it comes to shape and therefore cannot be correlated with fluvial transport and waving processes (Bala 2012).

For comparison, it is worth mentioning the research at Wigry Lake led by Rutkowski (Rutkowski 2001; Rutkowski et al. 2003). In studies it has been proven that, for lakes such as Wigry, which are of glacial origin, there is visible clast sorting and pebble shapes demonstrate features typical of marine beaches. The most frequently occurring types at Wigry Lake are discoid and blade shaped pebbles, which form $81 \%$ and $15 \%$, respectively, of all pebbles examined. 
MISCELLANEA GEOGRAPHICA - REGIONAL STUDIES ON DEVELOPMENT

Vol. $20 \cdot$ No. $2 \cdot 2016 \cdot$ pp. 46-53 • ISSN: 2084-6118 • DOI: 10.1515/mgrsd-2016-0013
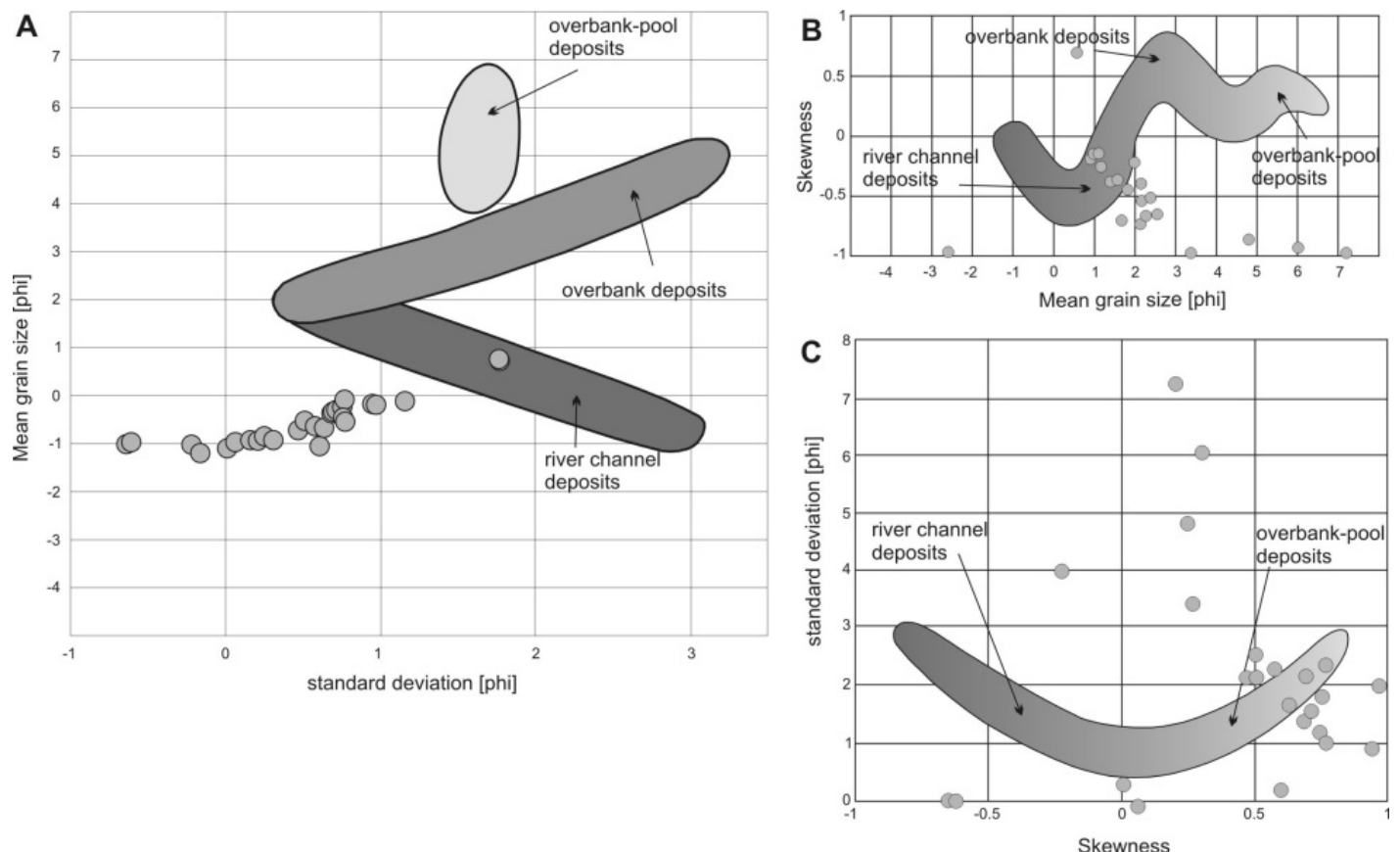

Figure 8. Relationships of Folk \& Ward textural parameters (after Mycielska-Dowgiałło \& Ludwikowska-Kędzia 2011)

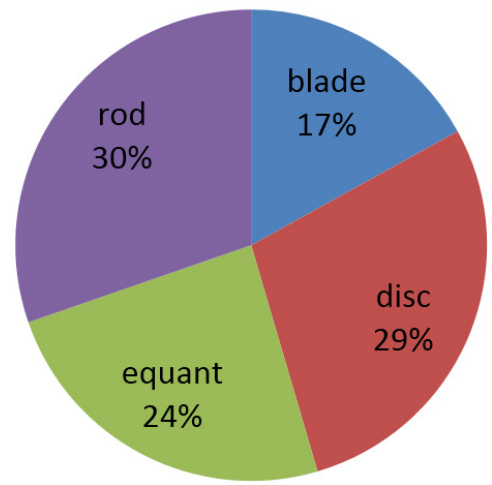

Figure 9. The mean percentage of clast shapes on beaches

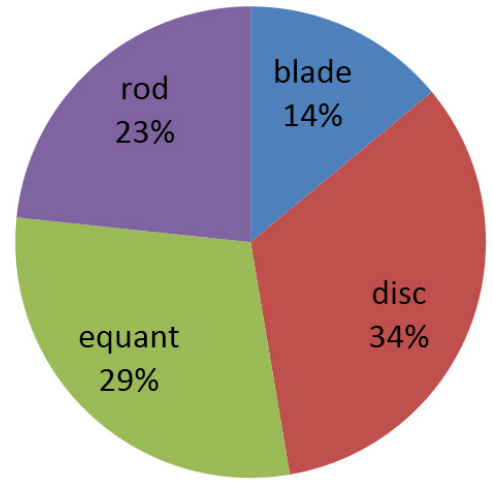

Figure 10. The mean percentage of clast shapes on cliffs

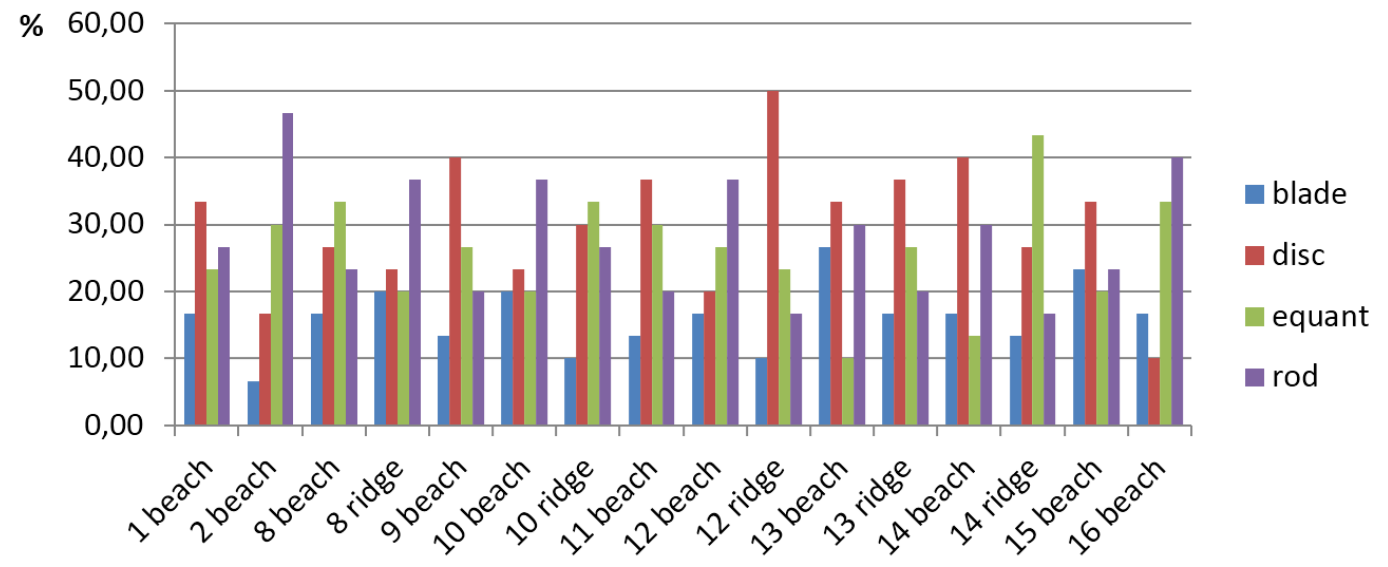

Figure 11. The percentage of clasts' shapes on all examined forms 
The MPS (maximum projection sphericity) index and OP (oblate-prolate) index (Dobkins \& Folk, 1970) were calculated for all examined pebbles, according to Sneed \& Folk's diagram (1958). Based on the MPS index, it is possible to separate fluvial from lacustrine sediments. An MPS value of $<0.66$ characterises lacustrine sediments, while $>0.66$ characterises fluvial sediments. The OP index allows the identification of the shapes of pebbles. A value of $\mathrm{OP}=0$ is characteristic for blade shaped pebbles, OP $>0$ for rod and OP $<0$ for discoid shaped pebbles (Dobkins \& Folk 1970). The further analysis of the examined clasts involved two more indexes - the elongate index and the flatness index, according to Wentworth (1922) - where an elongate index with a value $\geq 1.5$ characterises elongated pebbles and a flatness index $\geq 2.5$ describes flat pebbles.

The mean value of the MPS index for the examined pebbles was in the range $0.65-0.75$. More than $50 \%$ of the clasts had a value of over 0.66: this indicates fluvial influences on the sediment's character. The mean value of the OP was $>0$ (Bala, 2012), which is characteristic of fluvial environments, and suggests that the pebbles deposited on the beaches come from gills flowing into the lake.

This also confirms the influence of the fluvial process on the examined sediments. Lake water movements do not play a large role in forming beach sediments at Wast Water.

$80-90 \%$ of beach and cliff sediments are represented by flatness index values of $\leq 2.5$, which indicates a large proportion of non-flattened pebbles. When considering the mean flatness index values for all beaches and cliffs, it appears that there are no flattened clasts in the examined forms, as none of the values exceed 2.5. There is a different situation when it comes to the elongate index. On the beaches, about $50-60 \%$ of pebbles have values of $\geq 1.5$ and therefore elongated clasts are characteristic of a fluvial environment. However, in the cliffs only $30-40 \%$ of pebbles have values indicating elongated shapes. The biggest occurrence of pebbles with values of $\geq 2.5$ is on the river deltas $(1,13,14$, 15) (Fig. 12). At sites 2 and 16, according to this method, only non-flattened clasts are represented. Analysing clasts from the cliffs reveals a majority of pebbles with a value of $\geq 2.5$ in the north-eastern part of the lake $(12,13,14)$ (Fig. 13). In most cases, there is a greater occurrence of flat pebbles in the cliffs than on the beaches adjacent to them. Taking into account the mean values of the elongated index, it appears that these index values do not exceed 1.5 on only two beaches (beaches 9 and 11), while on the rest of the beaches the mean value is in the range 1.51 to 1.56 . When taking into account the fact that the cliffs' values of the elongated index are less than 1.5 , it is clear that the examined clasts have not been changed to a great extent by either fluvial transport or waving. This may be due to the presence of attrition-resistant hard volcanic rocks.

The process mentioned probably influences the clast shapes on the beaches adjacent to the cliffs. In the case of the elongated index, there is no such relationship, since a majority of elongated clasts is found in every part of the lake except sites 9 and 11 , where elongated clasts make up $30 \%$ of all measured clasts. In the cliffs adjacent to beaches and deltas there are less than $40 \%$ elongated clasts, while on the beaches, clasts make up $50-$ $60 \%$ of all elongated forms (Fig. 14-15). The elongated clasts may be the result of fluvial transport and the clasts' deposition on the delta.

The results of the flatness and elongated indexes confirm the thesis of the relatively small influences of waving processes on the sorting of pebbles on Wast Water's beaches, as opposed to fluvial transport and glacial origin sediments.

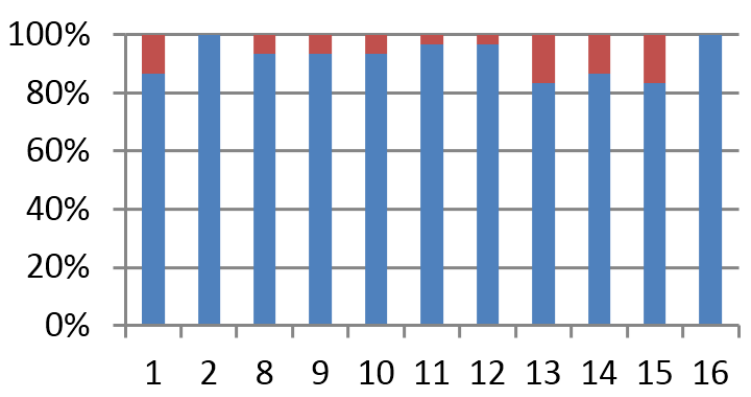

Figure 12. Flatness Index - beaches

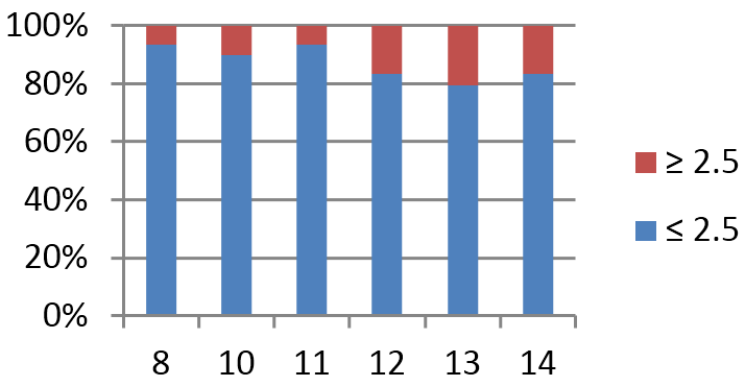

Figure 13. Flatness Index - cliffs

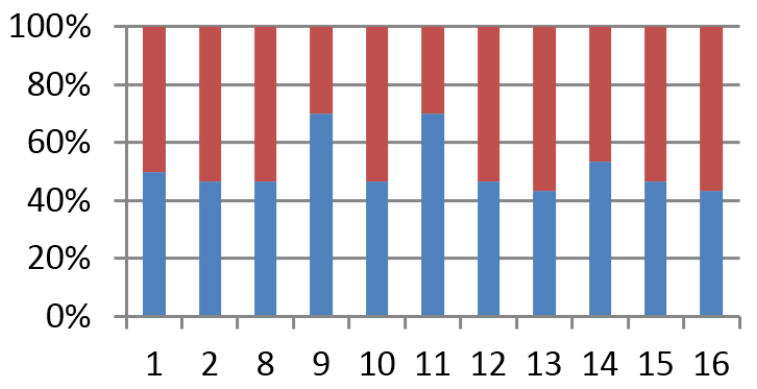

Figure 14. Elongated Index - beaches

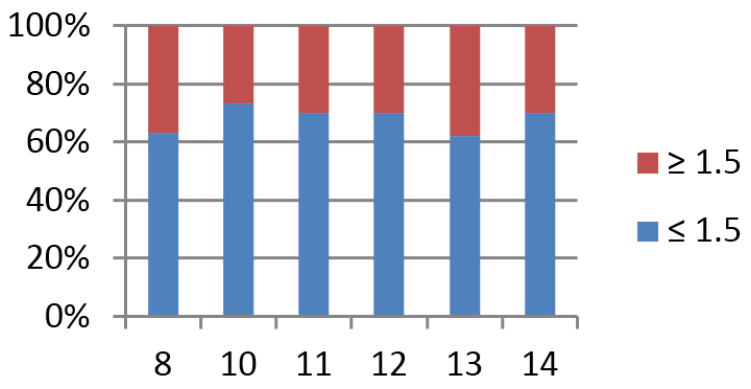

Figure 15. Elongated Index - cliffs

\section{Summary}

The field work, laboratory analyses and literature review lead to the conclusions presented below. The main purpose of the research was to identify the textural features of sediments deposited on the beaches of Wast Water Lake. The examined region consists of hard volcanic rocks. Weathering and attrition 
processes of bigger clasts are not visible. In this region, wave processes are not very intensive, due to an orographic barrier in the form of Wasdale, which is situated along the whole southeast shore of the lake. Most winds come from the south (60\%) (Ratcliffe 2002). Waves only develop on the lake when the wind comes from other directions. Even then, the waves are too small to influence the beach sediments (Beven \& Carling 1994). However, relatively frequent water level changes are observed in the range of up to hundreds of millimetres.

The biggest influence on the beach sediments comes from the rivers that flow into the lake, which bring rocks from the hills surrounding the lake. This is most visible in the pebble shape classification where most of the clasts are rod and blade shaped, which is typical of rolling transport (lllenberger 1991). For lacustrine beaches, on the other hand, the characteristic pebble shapes are discoid and equant (Rutkowski 2001). The sediments that were examined in the grain size distribution analysis were poorly sorted, which indicates that the transport of sediment was dynamic and deposition rapid, as happens in rivers. The only signs of water movement are the active till edges next to the beaches. Sediments there were also found to be better sorted.

The small influence of water movement on beach sediments at Wast Water Lake can mainly be attributed to the fact that the lake is rather small $\left(2.8 \mathrm{~km}^{2}\right)$ and quite young - about 10 thousand years. On small lakes, waves are limited in size, which is why processes in the shore zone are not very intensive (Pickrill 1985; Nordstrom \& Jackson 2012). The other reason is that the area is made up of hard, volcanic rock, which is weathering- and abrasionresistant. In summary, all figures show that fluvial processes have the greatest influence on the textural features of beach sediments for this study area.

\section{References}

Bala, E 2012, 'Strefa brzegowa i charakter osadów plażowych jeziora Wast Water (NW Anglia)', Zeszyty Naukowe Szkoły Wyższej Przymierza Rodzin seria geograficzno-turystyczna, vol. 5 (9), pp. 101-126

Beven, K \& Carling, P (eds) 1994, 'Floods: hydrological, sedimentological and geomorphological implications', Willey J. and Sons, Chichester

Bluck, BJ 1999, 'Clast assembling, bed-forms and structure in gravel beaches', Transactions of the Royal Society on Edinburgh Earth Sciences, vol. 89, pp. 291-323

Bluck, JB Ward, JD \& Spaggiari, R 2001, 'Gravel Beaches of Southern Namibia' in Ecology and Geomorphology of Coastal Shingle eds JR Packham, RE Randall, RSK Barnes, A Neal, Westbury Academic and Scientific, Yorkshire, pp. 56-76

Boardman, J 1991, 'Glacial deposits of the English Lake District' in eds J Ehlers, PL Gibbard \& J Rose Glacial deposits in Great Britain and Ireland, A.A. Balkema, Rotterdam, pp. 175-183

Boardman, J 1996, 'Classic land forms of the Lake District' The Geographical Association, Oxford

British Geological Survey 1998, Ambleside. England and Wales Sheet 38 Solid and Drift Edition. 1:50 000 Keyworth Notthingham

Cahill, RA 1981, 'Geochemistry of recent Lake Michigan sediments', Survey Circular 517, Illinois State Geological, Champaign

Dashtgard, SE Gingras, MK Butler, KE 2006, 'Sedimentology and stratigraphy of a transgressive, muddy gravel beach Waterside Beach Bay of Fundy Canada', Sedimentology, vol. 53, pp. 279-296

Dobkins, JE \& Folk, RL 1970, 'Shape Development on Thaiti Nui', Journal of Petrology, vol. 40, no. 4, pp. 1167-1203

Folk, RL \& Ward, C 1957, 'Brazos River bar a study in the significance of grain size parameters', Journal of Sedimentary Petrology, vol. 27, no. 1, pp. 3-26

Hart, BS \& Plint, AG 1995, 'Gravelly shore face and beachface deposits', Special Publications of the International Association of Sedimentologists, vol. 22, pp. 75-99

Harvey, AM 1997, 'Fluvial geomorphology of north-west England' in Fluvial Geomorphology of Great Britain ed. KJ Gregory, Geological Conservation Review, Series 13, Chapman and Hall, London, pp. 173-200

Herdendorf, CE 1973, 'Shoreline changes of Lakes Erie and Ontario with special reference to currents sediment transport and shore erosion' in Clear Technical Report no. II, Center for Lake Erie area research, The Ohio State University, Columbus
Hilton, J 1985, 'A conceptual framework for predicting the occurrence of sediment focusing and sediment redistribution in small lakes', Limnology and Oceanography, vol. 30, pp. 1131-1143

Hilton, J Lishman, JP \& Allen, PV 1986, 'The dominant processes of sediment distribution and focusing in a small, eutrophic, monomictic lake', Limnology and Oceanography, vol. 31, no. 1, pp. 125-133

Illenberger, WK 1991, 'Pebble shape (and size!)', Journal of Sedimentary Petrology, vol. 61, no. 5, pp. 756-767

Kemp, AES 1996, 'Laminated sediments as palaeo-indicators', Geological Society, London, Special Publications, vol. 116 (1)

Kemp, ALW Anderson, TW Thomas, RL Mudrochova, A 1974, 'Sedimentation Rates and Recent Sediment History of Lakes Ontario, Erie and Huron', Journal of Sedimentary Petrology, vol. 44, no. 1, pp. 207-218

Kirk, RM Komar, PD Allan, JC Stephenson, WJ 2000, 'Shoreline Erosion on Lake Hawea, New Zealand, Caused by High lake levels and Storm-Wave Run up', Journal of Coastal Research, vol. 16, no. 2, pp. 346-356

Korolec, H 1968, 'Procesy brzegowe i zmiany linii brzegowej Jeziora Mikołajskiego', Prace Geograficzne IGPAN, vol. 73

Ludwikowska-Kędzia, M 2000, 'Ewolucja środkowego odcinka doliny rzeki Bełnianki w późnym glacjale i holocenie', Dialog Press, Warszawa

Meyers, PA \& Lallier-Vergès, E 1999, 'Lacustrine sedimentary organic matter records of Late Quaternary paleoclimates', Journal of Paleolimnology, vol. 21, pp. 345-372

Millward, D Johnson, EW Beddoe-Stephens, B Young, B Kneller, BC Lee, MK \& Fortley NJ 2000, 'Geology of the Ambleside district, Memoir for 1:50 000 Geological Sheet 38 (England and Wales)', British Geological Survey, London

Mycielska-Dowgiałło, E \& Ludwikowska-Kędzia, M 2011, 'Alternative interpretations of grain-size data from Quaternary deposits', Geologos, vol.17 (4), pp. 189-203

Mycielska-Dowgiałło, E \& Rutkowski, J (eds) 1995, 'Badania osadów czwartorzędowych: wybrane metody i interpretacja wyników', Wydział Geografii i Studiów Regionalnych UW, PIG, Komisja Litologii i Genezy Osadów Czwartorzędowych Komitetu Badań Czwartorzędu PAN, Warszawa

Mycielska-Dowgiałło, E \& Rutkowski, J (eds) 2007, 'Badania cech teksturalnych osadów czwartorzędowych i wybrane metody oznaczania ich wieku', The Family Alliance School of Higher Education Press, Warsaw

Mycielska-Dowgiałło, E Ludwikowska-Kędzia, M 2011, 'Alternative interpretations of grain size data from Quaternary deposits', Geologos, vol. 17, no. 4, pp. 189-203 
Neal, A Pontee, NI Pye, K \& Richards, J 2002, 'Internal structure of mixed sand and gravel beach deposits revealed using ground penetrating radar', Sedimentology, vol. 49, pp. 789 804

Nordstrom, KF \& Jackson, NL 2012, 'Physical processes and landforms on beaches in short fetch environments in estuaries, small lakes and reservoirs a review', Earth Science Review, vol. 111, no. 1-2, pp. 232-247

Pickrill, RA 1985, 'Beach changes on low energy lake shorelines. Lakes Manapouri and Te Anau, New Zealand', Journal of Coastal Research, vol. 1, no. 4, pp. 353-363

Ratcliffe, D 2002, 'Lakeland, the wildlife of Cumbria', Harper Collins Publishers, London

Rutkowski, J 2001, 'Uwagi o segregacji żwirów w środowisku plażowym nad jeziorem Wigry', Sprawozdanie z czynności $i$ posiedzeń PAU, vol. 14, pp. 192-194

Rutkowski, J Król, K Krysztofiak, L \& Prosowicz, D 2003, 'Współczesne osady jeziora Wigry (Plos Bryzglowski)', Prace Komisji Paleogeografii Czwartorzędu PAU, vol. 1, pp. 39-45

Schelske, CL \& Hodell, DA 1995, 'Using carbon isotopes of bulk sedimentary organic matter to reconstruct the history of nutrient loading and eutrophication in Lake Erie', Limnol. Oceanogr., Vol. 40, no. 5, pp. 918-929

Sly, PG 1978, 'Sedimentary processes in lakes' in Lakes: chemistry, geology physics, ed. A. Lerman, Springer Verlag, New York, pp. 65-89

Sneed, ED \& Folk, RL 1958, 'Pebbles in the lower Colorado River, Texas, A study in particle morphogenesis', Journal of Geology, vol. 66, pp. 114-150

Srinivas, R \& Sajan, K 2010, 'Significance of textural analysis in the sediments of Kayamakulam lake, southwest coast of India', Indian Journal of Marine Sciences, vol. 39, no. 1, pp. 92-99

Starkel, L 1998, 'Sediments in shore zone of Lake Gościąż' in Lake Gościąż, Central Poland a Monographic Study, Part 1, eds M Ralska-Jasiewiczowa, T Goslar, T Madeyska, L Starkel, W. Szafer Institute of Botany, Polish Academy of Sciences, Kraków, pp. 90-91
Thomas, RL Kemp, ALW \& Lewis, CFM 1972, 'Distribution, composition and characteristics of the surficial sediments of Lake Ontario', Journal of Sedimentary Petrology vol. 42, no. 1, pp. 66-84

Thomas, RL Kemp. ALW \& Lewis, CFM 1973, 'The surficial sediments of Lake Huron', Canadian Journal of Earth Sciences, vol. 10, pp. 226-265

Tian, J Nelson, DM \& Sheng Hu, F 2011, 'How well do sediment indicators record past climate? An evaluation using annually laminated sediments', Journal Paleolimnological, vol. 45, pp. 73-84

Tylmann, W 2011, 'Jeziorne osady rocznie laminowane w północnej Polsce: aktualny stan rozpoznania, postępy metodyczne i perspektywy badawcze', Studia Limnologica et Telmatologica, vol. 5, no. 1, pp. 23-41

Webb, A Martin, E Greet, J Kennedy, D 2012, 'An analysis of Lake Victoria vegetation and shoreline monitoring data. Final report', Authority for and on behalf of the Commonwealth of Australia

Wentworth, CK 1922, 'A scale of grade and class terms for clastic sediments', The Journal of Geology, vol. 30, no. 5, pp. 377392

Wicik, B \& Więckowski, K 1991, 'Osady jezior „Na Jazach” w Kotlinie Płockiej - warunki ich akumulacji oraz rola w rekonstruowaniu i prognozowaniu przekształceń środowiska naturalnego', Przegląd Geograficzny, vol. 63, 1-2, pp. 57-76

Winter, M 2012, 'Classification of gravel component lake beaches in the South Island, New Zealand', Unpublised Master thesis, University of Otago (https://otago.ourarchive.ac.nz/ bitstream/handle/10523/3850/WinterMargaretSA2013MSc. pdf? sequence $=1$ \&isAllowed $=y$ )

Zingg, T 1935, 'Beitrag zur Schotteranalyse: Die Schotteranalyse und ihre Anwendung auf die Glattalschotter', Schweizerische Mineralogische und Petrographische Mitteilungen, vol. 15, pp. $39-140$ 